\title{
Correction to: Correlation between functional ability, toe flexor strength, and plantar pressure of hallux valgus in young female adults: a cross-sectional study
}

Mieko Yokozuka ${ }^{\text {** }}$, Kanako Okazaki ${ }^{1}$, Yuko Sakamoto ${ }^{2}$ and Koko Takahashi ${ }^{2}$

Correction to: J Foot Ankle Res (2020) 13: 44

https://doi.org/10.1186/s13047-020-00411-1

Following publication of the original article [1] the authors have notified us of an error in the first row of Table 1:

Incorrect values: $20.3 \pm 5.1(4-15) 11.0 \pm 2.6(16-43)$

Correct values: $20.3 \pm 5.1(16-43) 11.0 \pm 2.6(4-15)$

\section{Author details}

${ }^{1}$ Preparing Section for New Faculty of Medical Science, Fukushima Medical, University, 1 Hikariga-oka, Fukushima 960-1295, Japan. ${ }^{2}$ School of Nursing, Fukushima Medical University, 1 Hikariga-oka, Fukushima 960-1295, Japan.

Published online: 07 August 2020

\section{Reference}

1. Yokozuka M, et al. Correlation between functional ability, toe flexor strength, and plantar pressure of hallux valgus in young female adults: a cross-sectional study. J Foot Ankle Res. 2020;13:44. https://doi.org/10.1186/ s13047-020-00411-1.

The original article can be found online at https://doi.org/10.1186/s13047020-00411-1.

* Correspondence: yokozuka@fmu.ac.jp

${ }^{1}$ Preparing Section for New Faculty of Medical Science, Fukushima Medical, University, 1 Hikariga-oka, Fukushima 960-1295, Japan

Full list of author information is available at the end of the article

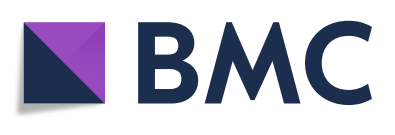

(- The Author(s). 2020 Open Access This article is licensed under a Creative Commons Attribution 4.0 International License, which permits use, sharing, adaptation, distribution and reproduction in any medium or format, as long as you give appropriate credit to the original author(s) and the source, provide a link to the Creative Commons licence, and indicate if changes were made. The images or other third party material in this article are included in the article's Creative Commons licence, unless indicated otherwise in a credit line to the material. If material is not included in the article's Creative Commons licence and your intended use is not permitted by statutory regulation or exceeds the permitted use, you will need to obtain permission directly from the copyright holder. To view a copy of this licence, visit http://creativecommons.org/licenses/by/4.0/. The Creative Commons Public Domain Dedication waiver (http://creativecommons.org/publicdomain/zero/1.0/) applies to the data made available in this article, unless otherwise stated in a credit line to the data. 